\title{
Collaborative Innovation in Food SMEs: A Practice Approach
}

\author{
Angela Caridà \\ Department of Legal, Historical Economic and Social Science \\ University of Catanzaro "Magna Græcia”, Catanzaro, Italy \\ angela.carida@unicz.it \\ Maria Colurcio \\ Department of Legal, Historical Economic and Social Science \\ University of Catanzaro "Magna Græcia”, Catanzaro, Italy \\ mariacolurcio@unicz.it
}

\begin{abstract}
The work focuses on the collaborative innovation. It emphasizes the role of relationship and of the resource integration process for the development on innovation and aims to define a practice to support management in the development and fostering of networked innovation process in SMEs. This paper addresses the topic of collaborative innovation in the food SMEs by presenting the results of two studies. The study 1 concerns empirical evidences from 155 Italian food SMEs. It describes the state of the art of the innovation in the Italian food SMEs context. The study 2 relates an in-depth analysis of 10 Italian food SMEs. It frames the innovative behaviour of the firms investigated according to the practice theory.
\end{abstract}

Keywords: Collaborative innovation, resource integration, practice, SMEs, food context

\section{INTRODUCTION AND OBJECTIVES}

Over the last two decades, a radical change affected the way that academics consider innovation [1] and firms develop innovatory activities [2]. Innovation stems from an interactive process between the firm and its environment [3] and requires the setting up of strong relationships among different parties from different organizations $[4,5]$. Consistent with this approach, the topic of "collaborative innovation" focuses on the access to networks to ride out the limits and the barriers to innovation [6]. It is acknowledge by scholars and practitioners as the dominant perspective in the innovation literature in last decade.

In the SMES context the collaborative innovation approach becomes more and more important as participation in networks and engagement in partnerships allows SMEs to tackle new technological and market frontiers and to cope with the fast changing environment $[7,8,9]$. Previous studies pointed out the increasing interest of SMEs in collaboration with other organizations [7, 8], as the integration between internal and external resources (customers, suppliers, competitors, universities and others) enhances the SMEs ability to innovate [10]. According to a marketing perspective, the interaction between partners is the antecedent of resource integration, "through their interactions, partners transfer knowledge and other resources in developing organizational learning; [...] knowledge, skills and other resources are integrated to put together a network of firms possessing a set of competencies capable of offering a value innovation that is an innovative value proposition which enable higher value 
co-creation" [11]. Thereby, networks are for SMEs a complementary response for creating successful innovations [2] and for triggering resource-integration processes.

Despite of the rich and well-established literature on the topic of collaborative innovation in the SMEs context, no studies, to the authors knowledge, have been found on collaborative innovation as a practical phenomenon. Therefore, dynamics which cause such practices are unclear. More generally, this is confirmed by the lack of contributions on the relevant topic of how to organize practice for strategic ends [12], such as innovation. Indeed, with the except for few studies [13], the strategic connection of the practice theory to the managerial issues of innovation and competitive advantage is still underdeveloped.

The route we choose to address this gap, is to focus on the analysis of collaborative innovation practices within a specific SMEs context, the Italian food business ${ }^{1}$. The empirical study we conducted is framed in a marketing perspective and focuses on the interactive process between the partners of the network and on the integration between external and internal resources of the focal company.

This study is twofold. First of all, it aims to contribute to the theoretical debate on collaborative innovation in SMEs context according a marketing view emphasizing the key role of resource integration for the development of a value innovation. Secondly, it aims to define a practice to support SMEs to manage network relationship for innovation and to extract value through resource integration process. In order to reach the second goal of the study, we adopt a practice-based view [15, 16]. Paraphrasing Kjellberg et al., (2012) [17], a practice approach invites a wider perspective on whose activities and which activities make and shape collaborative innovation. It allows us to frame the process aspects [18], of collaborative innovation and to define how collaborative innovation practices emerge and how they can contribute to leverage the innovative performance of the Italian food SMEs.

\section{CONCEPTUAL FRAMEWORK}

This study developed from two main theoretical streams of research, i) studies on innovation from a practice based view and ii) research on the innovation within the food context.

\section{Innovation and practice theory}

Practice theory draws on a view that social reality consists of a nexuses of practices [16] that make action and order possible [19]. By focusing on how something happens and what consequences [20], the practice based theory has been adopted to analyse various phenomena [21].

Although studies on innovation from a practice based approach are still in an infancy stage [13], practice theory is becoming a central notion for understanding innovation [22, 13]. According to Korkman et al. (2010) [22], the practice-based view perceives innovation as a set of innovative practice (actions) that are formed as the resources of customers and providers interlink with different contextual elements [23]. Activities, together with actors, are a central

\footnotetext{
${ }^{1}$ Reasons we decided to investigate Italian food SMEs were mainly two. First, because food firms require the combined efforts of different partners of the network(e.g. suppliers and retailers) to realize successful innovations and to customise new products to the needs of the end-consumers [6],. Second, food SMEs are one of the most important sector in the Italian economy. In fact, despite of the higher level of product competitiveness from emerging countries e.g. lower labor costs and greater market penetration capacity - [36], this sector contributes strongly to the development and competitiveness of the Italian economic system by representing the $13 \%$ of firms and the $10 \%$ of employees of the whole manufacturing system [14].
} 
theme in strategy-as-practice [24]. Actors interact through practical activities, such as actions or micro-processes, towards a strategic goal and expect outcome. Over time, actors develop patterns of actions and routines that can be identified as strategic practices. The concept of practice is not synonymous with action. It expands the unit of analysis to the system that fosters action [25], involving the subject, the action, the tools and the context in which the integration of many resources occurs [23].

Hence, investigating innovation through the practice lens implies the joint analysis of these elements, as well as, the idea that innovation emerges from an interactive process performed by many actors.

According to this perspective, we address the topic of collaboration as a key theme for the development of innovation practices. Paraphrasing the notion of market practice [17] and combining it with the topic of collaborative innovation $[4,5]$ we stated that "collaborative innovation practices are enacted through - routine, micro-level inter-actions between multiple actors who integrate their resources seeking to create value for themselves and other by developing something new and better".

\section{Innovation in food industry}

"However in SMEs, resource restrictions may limit the development of a wide range of innovations. The establishment of network relations can provide an avenue to address this problem" [26].

External innovation partnerships provide SMEs with the stimulus and capacity to innovate [2], fostering firms access to resources, complementary skills, capabilities and knowledge that are not internally available [27].

Collaborative networks affect positively the innovative performance of SMEs, by impacting on the degree of innovation novelty $[7,28]$ - e.g. inter-firms cooperation pursues radical and incremental innovations [29] - and on both product and process innovation [30]. According to Avermaete et al., 2004 [31], the concept of innovation we propose in this work goes beyond radical and technology based product innovation. It includes incremental changes in product and process, in the organizational structure as well as the exploring of new market.

Despite of the food sector maturity [10], the lack of R\&D investments and the product innovation riskiness [32], food SMEs take on innovation to satisfy new regulatory standards, to become more efficient in processing activities, to develop new products and to better satisfy the customers' needs [31]. Previous study [6], viewed the network relations as the more suitable way to innovate. Similarly, to other manufactures context, strategic alliances in the food industry concern mainly the supplier-buyer relationships [28, 33]. They have the potential to affect the food firm competitiveness by increasing the product quality and by allowing SMEs to satisfy the new market demand for more complex products [34] that are commercially successful [35].

Studies on innovation in food SMEs [36, 37, 38] seem don't converge toward a common output. For some authors food SMEs are engaged in both product and process innovations [35], whereas for others, food firms are mainly focused on incremental innovation and on process innovations instead of product innovations [31, 37,38]. By including the researches cited above, contributions on innovation in food SMEs embrace different topics, such as the drivers and types of innovation [37, 38, 39]; the innovation and export behaviour relationship [40]; the 
networking approach to innovation [6] and its effects on product and process innovativeness [41]; the link between innovation and the food SMEs performance [42]. There has been little previous research on innovation practices of food SMEs [38]. The literature review reveals the lack of researches on collaborative innovation from a practice based view to define concretely the process aspects and the key elements of such practices as well as how they can contribute to leverage the innovative performance of food SMEs.

\section{METHODOLOGY}

Given the lack of prior empirical research addressing the topic of collaborative innovation practice in the SMEs context, we adopted an exploratory approach. This paper addresses the topic of innovation and the effects of collaborative innovation in the food SMEs by framing two studies: study 1 and study 2 .

\section{Study 1}

The study 1 concerns empirical evidences from 155 Italian food SMEs. It describes the state of the art of the innovation in the Italian food SMEs context. Data were collected through an online questionnaire that has been sent to 250 food SMEs (selected from Cerved Database 2010 by the geographical distribution). The questionnaire allows us to gather a large amount of data to profile organizations [43] and to frame innovation in the Italian food context. The questionnaire included many closed questions concerning the bent of firms toward innovation and their innovative behaviour (type of innovation achieved, engagement in incremental and/or radical innovation etc.), as well as, the involvement of firms in networks for innovation.

We used a dichotomous variable to understand if firms had innovated from 2009-2012. Additional information were asked if not, to understand the reasons of a such conservative behaviour. Questions on types and on the degree of innovation were followed by specific queries relating partners. Additional information were asked when respondents declared to have no external partners, as we consider this variable relevant to recognize elements limit the raise of innovation networks. Final questions relate the profile of companies (size, product range, revenue etc.).

The number of questionnaires we received was 180; among these,155 were fully complete. The resulting sample relates155 processing food SMEs located in the north, central and south of Italy. The sample includes firms different in size $(<10$ employees; small: $<50$ employees; medium: $<250$ employees), revenue, geographical market served and products range (drink and beverage, fresh and processed food) (table 1).

Table 1: Study 1 Sample Profile

\begin{tabular}{l|l|l}
\hline & Criteria & $\%$ \\
\hline \multirow{3}{*}{ Product group } & Drink and beverage & 23,9 \\
& Fresh food & 17,4 \\
& Processed food & 58,7 \\
\hline \multirow{3}{*}{ Size: employees number } & Up to 9 & 5,8 \\
& 10 to 50 & 83,2 \\
\hline & 51 to 250 & 11 \\
\hline \multirow{5}{*}{ Revenue $(\boldsymbol{(})$} & Up to $500.000,00$ & 3,2 \\
& $501.000,00-1.000 .000,00$ & 1,9 \\
& $1.100 .000,00-2.000 .000,00$ & 9,1 \\
& $2.100 .000,00-5.000 .000,00$ & 24,7 \\
& $5.100 .000,00-10.000 .000,00$ & 24 \\
& $10.100 .000,00-50.000 .000,00$ & 33,8 \\
& Over $50.100 .000,00$ & 3,2 \\
\hline
\end{tabular}




\begin{tabular}{l|l|l}
\hline \multirow{2}{*}{ Geographic markets served } & Only regional & 8,4 \\
& National & 16,8 \\
& International & 74,8 \\
\hline
\end{tabular}

\section{Study 2}

The study 2 relates to the in-depth analysis of 10 Italian food SMEs according to the practicebased approach. It focuses on the relationship with partners engaged by the SMEs within innovation network.

Data and information were collected through telephonic, skype video-chat interviews and direct interviews to the marketing managers and innovation managers (or equivalent) of 10 agri-food SMEs (processing stages of the agri-food vertical chain) [44]. The ten processing firms we focused on, have been selected between the 67 SMEs that innovate with partners (study 1). Two or more people per company have been interviewed. Each interview lasted approximately forty minutes.

The interview form has been characterized by an open [45] and dialogical structure for the understanding of the experience(s) and stories of the respondents. Open questions related to the engagement of firms within the innovation network and mainly: i) the actors' characteristics (type of partners engaged: suppliers, retailers, customers and university/research centres etc; ii) the content of the relationship (business - sale agreementstechnological, marketing, etc.); iii) the duration and evolution of the relationship; iv) the effects of partnerships (e.g. economic, technological, cognitive and market) and v) the interviewees' opinion and commitment toward the relationship. Open questions reflect the research construct we elaborated on the basis of previous practice research [13, 22] and of collaborative and network innovation studies $[4,5,6]$. The research construct includes actors, roles, activities [46], the main content and the concrete value co-created through the relationship (Figure 1).



Figure 1: The research construct.

\section{FINDINGS}

\section{Study 1: The state of the art of the innovation in the Italian food SMEs}

Empirical data showed some interesting insights about the innovation in the Italian food Smes. The 125 firms $(80,6 \%$ of the sample) () who declared to have introduced product and/or process innovation from 2009 to 2012, are aware of the relevance of innovation to improve market competitiveness. On the contrary 30 firms $(19,4 \%)$ showed a conservative behavior. The $43,4 \%$ of the non-innovative firms identified the lack of resources as the main cause of it, whereas, for the $23,3 \%$ of the interviewees, the resistance to the innovation is due to the lack 
of government support. Just few people indicated the economic and financial crisis $(6,7 \%)$ and the lack of partners $(6,7 \%)$. In some cases $(20 \%)$ interviewees indicated the peculiarities of their product (i.e. parmesan cheese, mozzarella cheese.) and the observation of strict standards of production as the main limits to innovation.

We used dichotomous variables to understand if firms have developed product or process innovation or both. Differently from previous study [37] our data reveal the mild prevalence of the product on process innovation $(81,6 \%$ vs 69,7$)$, and that both types of innovations are contextually developed. Indeed, the 51\% of the sample (64 firms) have declared to be involved jointly in product and process innovation. Moving on the topic of the network relationships, we asked to innovation managers about the engagement of company within innovation networks. The half of the sample $(53,6 \%)$, that include the $64 \%$ of the firms engaged in both product and process innovation, declared to have developed innovation in cooperation with external partners (also more than one ), while, for the 45\% of interviewees external support is not necessary to innovate. Moreover, the resistance to cooperate can depend on the lack of available partners $(24,1 \%)$ or on the keep of the new projects secrecy $(5,2 \%)$.

\section{Study 2: The collaborative innovation practice. \\ 4.2.1 Actors and roles}

In the matter of innovation relationships, data we elaborated pinpoint suppliers (both of raw material, equipment and services) as the favourite and strategic partner for SMEs (named by 5 firms). Suppliers are a relevant source of innovation; they provide important input in the realization of new products through new materials and new applications. Suppliers contribute to innovation processes by providing different kinds of input (competencies, technology, and consultancy), as emphasized by the marketing manager of a diary company:

"Our first partner in innovation is our packaging supplier; thanks to his proposal we have been able to develop a new cheese with great appeal. The supplier not only advised a new product (a window packet), but he helped us to use it as marketing tool. Through window packets, today we propose an offer of mozzarella cheese that is unique on the market".

On the other hand, in some cases (agri-food network), when suppliers are micro-family businesses (farmers) lacking in resources and competencies, the food processing Smes represent the joining link with the innovation network and the source of knowledge and competencies, as demonstrated by the following quote of a fresh cut company's marketing manager:

"At the beginning of the relationship, we were just self-focused. The important thing was quality products, punctuality of delivery, etc... Then, thanks to an open-minded commercial manager, the customer understood that in the long run, cooperation and daily talks with the production field would be necessary for good salads and for the continuous development of new products (fruits)".

Only few times the interviewees have indicated other players as favorite partner such as experts or specialists (named by 2 firms) and marketing agencies (named by 1 firm).

Suppliers support innovation by providing SMEs with new technical solutions and new ideas triggering learning processes. Expert and specialists contribute to increase or to bridge a competence gap developing new knowledge, whereas marketing agencies support firms during the launch of new products and in approaching market. Just few interviewees mentioned large distributors (named by 1 firm): 
"Thanks to the cooperation with company we developed a new offer of pasta (new shape, new size and new characteristics). The channel relationship we built together was, for us, the beginning of a path oriented toward the value creation for our customers".

The involvement of universities and research institutes is very week. In a company the relationship concerns the cooperation on a specific project, as showed by the following quote:

"We collaborated with a university just for the development of a new product. It was great, but now we are not in touch. There are a lot of ties to cooperation, first of all the lack of resources".

Partnerships with customers is not a relevant data, it is not named by firms investigated. For all the firms we investigated, the development of a collaborative relationship is very helpful because it supports firms in achieving strategic competitive information to better understand the business context and opportunities.

All partners act as resources integrators. Although with different intensity and manners due to their specific purpose and status, actors use and integrate the resources that they hold with the resources made available from the company. They integrate human - competence, skills and communication - as well as non-human resources - tools and equipment - to create a new organizational culture as the following quotes suggest:

"The things we learned from the supplier about the field are numerous and amazing, but we showed them things that they could not have ever imagined about laboratories, packaging and communication. Working together in the field, as in a laboratory, we can do great things!".

"Getting in touch with the supplier was a revolution. Before this friendly and cooperative relationship, we considered the raw material a non-flexible resource, a tie, but now we know that we can work miracles!"

\subsubsection{Activities}

Different activities were jointly implemented by actors to co-innovate. Activities can create value in their own right or can be instrumental in achieving value later on. Our analysis focused on the operational manners to work with partners. We account it as an instrumental approach to foster collaborative relationships for the development of innovation.

Activities unveiled by our study include the setting up of inter-firms team works, the recurring exchange of information and knowledge and the conjoint training course.

Drawing from information provided by respondents, six firms have been engaged in developing projects and new ideas together with other companies team. However, all respondents were aware of the importance to improve mechanism for information and knowledge sharing, just four SMEs have been engaged in a common path of vocational training. Paradoxically, these activities have been developed more by firms engaged in recent relationships (from 2 to 5 years) instead of firms engaged in long and well-established partnerships (more than 7 years). Interviewees involved in these activities affirmed that partnerships up to now, are not changed or evolved. This can depend on the age of relations (recent) as well as on the specific purposes of the relationship (just on well-defined projects). 


\subsubsection{Content}

Moving on the content of collaborative innovation practice, five specific topics - business (sale agreement), technological, marketing, financial and $R \& S$ - mark out firms' relationships in the Italian food context. Four firms have been engaged in technological partnership, while for three firms the main content of collaborative practice for innovation regarded R\&D. Just one firm has been engaged in business or marketing or financial partnerships. Of course these contents and their relevance vary according purposes, needs, status and the organizational system of firms.

\subsubsection{Value}

To analyse the effects of the SMEs engagement in collaborative innovation and thus its leverage on the firms innovative performance, we focused on the opinion of managers about the relationship. Results about value in innovation practice concern the value perceived by interviewees and not market value or performance of the company.

We identified the benefits produced by partners and the specific skills and knowledge firms developed together with partners. The most important benefits that respondents have identified in a collaborative approach to innovation are the co-generation of new ideas for the development of new and incremental product and of the process innovation (named by 4 firms); ii) the improvement of economic and market performances of firms, such as, the ROI (named by 2 firms) the revenue and the market share (named by 1 firm); iii) the engagement in new business relationships (named by 1 firm); iv) the support to access to new markets and technologies (named by 1 firm); and finally v) the acquisition of new knowledge and new competencies (named by 1 firm) such as the technological, informatics, marketing and business skills.

\section{DISCUSSION}

The studies we briefly reported above, hint two major insights. The study 1 surveys and profiles the approach of the Italian food SMEs to innovation in order to identify the types and the degree of innovation developed and the effects of firms involvement in innovation networks.

It defines the main elements of a practice to support management in the development of collaborative innovation in SMEs: actors, roles, activities, content and value. The research revealed the positive involvement of the Italian food SMEs in innovation process and their positive approach to collaborate with partners for innovation. Despite the existence of some barriers - economic, technical and cultural - that, enforce the conservative behaviour of a part of the interviewees, for the most part of companies, innovation activities are recognized as a priority to ensure the organisational success, the performance improvement and the survival in the competitive arena. SMEs use their knowledge and skills reactively according to the rules, procedures and clauses drawn down together with partners. The main benefits of such a practice may include the co-generation of new ideas, the improvement of the revenue as well the exchange of knowledge and the creation and absorption of competencies, skills, abilities etc.

The information coming up from direct interviews with managers showed that structural firms' characteristics (differences in size, revenue, products, and markets served) don't represent a barrier for supporting or being engaged in practices of collaboration.

The study 2 stressed main elements - actors, roles and activities - that enhance the collaborative practice for innovation in the Italian food context. 
Specifically, we recognized the aware of respondents about the key role of partners for the innovation development. Suppliers of equipment and raw material are the main partners of Italian food SMEs. They act as co-innovator partner, supporting processing firms to implement new ideas and especially new technical solutions. This is consistent with data on innovations investment in Italy, and confirms that the predominant Italian innovative food model is based on the firm's ability to absorb and integrate equipments' technology within their production process. According to [30] vertical cooperation has a higher significant impact on both product and process innovation.

The recurring share of information and knowledge is the main activity firms and partners carry-out to co-innovate. It can be viewed as the essential activity to co-innovate, also because, it affects both types and degree of innovation (e.g. product, process, incremental and radical). Indeed, knowledge that is created through the fully and actively engagement of people within the complete flow of activities that constitute the practice, is the source of potential innovation [12].

Interviewees reveal that more is the effort required to innovate more firms are pushed to foster more complex and well-structured activities including the setting up of inter-firms team works and conjoint training courses. According to Laursen and Salter (2006) [47], this study shows that openness through networking is complementary and beneficial to the innovation outcomes of firms, furthermore is the engagement within a collaborative network is the one and only way to match the rapid-changing of the market demand and to reach a wider set of results [10].

\section{Managerial Implications}

The studies emphasized the main elements - actors, roles and activities - shape the collaborative practice for innovation in the Italian food context, to foster a shared understanding of what the practice is and to keep these activities doable and meaningful.

As pointed by Ellström (2010) [48] "practice-based innovations can arise as a result of the interplay between, on the one hand, officially prescribed work processes - the explicit dimension - and, on the other hand, the work process as it is performed in practice with a considerable element of variation and improvisation". By considering the main features of the Italian SMEs food context - small size, family firms, resource scarcity etc - we believe it is important to shift the collaborative innovation practice from the implicit to the explicit dimension to acknowledge and codify it as a part of the organization formal structure. By this way, SMEs should frame and implement collaborative innovation practice to replace episodic with continuous innovation. Of course, this implies a continuous process of knowledge exchange that is constantly challenged by the variations and modification of network relations and by the firms innovative response to the market.

\section{Further Research}

The field of collaborative innovation in food SMEs is still at an early stage. It offers a broad and interesting area of study for both academics and practitioners. A great deal of management research should address the develop a managerial approach to acknowledge and codify the collaborative innovation practice as a part of the SMEs formal structure. Accordingly, further researches should focus on both the conceptualization and definition of procedures, methods and tools to systematise the collaborative innovation practice within the SMEs context. 


\section{ACKNOWLEDGMENTS}

The study reports the findings of the international research project: "Networked innovation in agribusiness SMEs" which has been supported by the European Social Fund and the Department 11 of the Region Calabria through the program "POR Calabria FSE 2007-2013Asse IV Capitale Umano-Obiettivo Operativo M2. The projects provided financial support for the researchers mobility and for the carrying on of the empirical investigation and the case study development.

\section{Reference}

[1] Russo Spena, T., and Colurcio, M., A cognitive-relational view of innovation in the agrifood industry: the fresh cuts business, International Journal of Innovation Management, 2010. 14(2): p. 307-29.

[2] Zeng, S. X., Xie, X. M., and Tam, C. M., Relationship between cooperation networks and innovation performance of SMEs, Technovation, 2010. 30(3): p. 181-194.

[3] Mention, A. L., Co-operation and co-opetition as open innovation practices in the service sector: Which influence on innovation novelty?, Technovation, 2011. 31(1): p. 44-53.

[4] Trott, P., and Hartmann, D., Why open innovation' is old wine in new bottles, International Journal of Innovation Management, 2009. 13(4): p. 715-736.

[5] Chesbrough, H., Open Business Models: How to Thrive in the New Innovation Landscape, Harvard Business School Press, 2006. Boston.

[6] Colurcio, M., and Russo Spena, T., Collaborative Innovation-A Focus on Food SMES, chapter 28, in Food Industry, Intech, 2013.

[7] Nieto, M. J., and Santamaría, L., Technological Collaboration: Bridging the Innovation Gap between Small and Large Firms, Journal of Small Business Management, 2010. 48(1): p. 44-69.

[8] Van de Vrande, V., De Jong, J. P., Vanhaverbeke, W., and De Rochemont, M., Open innovation in SMEs: Trends, motives and management challenges, Technovation, 2009. 29(6), 423-437.

[9] Lee, C., Lee, K., and Pennings, J. M., Internal capabilities, external networks, and performance: a study on technology-based ventures, Strategic management journal, 2001. 22(6-7): p. 615-640.

[10] Colurcio, M., Wolf, P., Kocher, P. Y., and Russo Spena, T., Asymmetric relationships in networked food innovation processes, British Food Journal, 2012. 114(5): p. 702 - 727.

[11] Mele, C., Spena, T. R., and Colurcio, M., Co-creating value innovation through resource integration, International Journal of Quality and Service Sciences, 2010. 2(1): p. 60-78.

[12] Dougherty, D., Organizing practices in services: capturing practice-based knowledge for innovation, Strategic Organization, 2004. 1: p. 35-64.

[13] Russo Spena, T., and Mele, C., Five Co-s in innovating: a practice-based view, Journal of Service Management, 2012. 23(4): p. 527-553.

[14] ISTAT (2011). Struttura e dimensione delle imprese. Statistiche in breve, ISTAT, Rome.

[15] Korkman, O., Customer Value Formation in Practice: A Practice Theoretical Approach. Svenska handelshögskolan, 2006.

[16] Schatzki, T.R., Knorr-Cetina, K., von Savigny, E., The Practice Turn in Contemporary Theory. Routledge, London, 2001.

[17] Kjellberg, H., Storbacka, K., Akaka, M., Chandler, J., Finch, J., Lindeman, S., and Nenonen, S., Market futures/future markets: Research directions in the study of markets, Marketing Theory, 2012. 12(2): p. 219-223.

[18] Andersson, P., Aspenberg, K., and Kjellberg, H., The configuration of actors in market practice, Marketing Theory, 2008. 8(1): p. 67-80.

[19] Bourdieu, P., Outline of a Theory of Practice. Translated by R. Nice, 1977. Cambridge. 
[20] Fuglsang, L., and Eide, D., The experience turn as 'bandwagon': Understanding network formation and innovation as practice. European Urban and Regional Studies, 2013. 20(4): p. 417-434.

[21]. Kowalkowski, C., Persson Ridell, O., Röndell, J. G., and Sörhammar, D., The co-creative practice offorming a value proposition, Journal of Marketing Management, 2012. 28(13-14): p. 1553-1570.

[22]. Korkman, O., Storbacka, K., and Harald, B., Practices as markets: value co-creation in e-invoicing, Australasian Marketing Journal, 2010. 18: p. 236-247.

[23]. Reckwitz, A., Toward a theory of social practices: a development in culturalist theorizing, European Journal of Social Theory, 2002. 5(2): p. 243-263.

[24]. Wikner, S., Value co-creation as practice: On a supplier's capabilities in the value generation process. JIBS Dissertation Series No. 068, 2010.

[25]. Dourish, P., Where the Action Is: The Foundations of Embodied Interaction, MIT Press, Cambridge, 2001.

[26] Gronum, S., Verreynne, M., L., and Kastelle, T., The Role of Networks in Small and Medium-Sized Enterprise Innovation and Firm Performance, Journal of Small Business Management, 2012. 50(2): p.257-282.

[27] Døving, E., and Gooderham, P. N., Dynamic capabilities as antecedents of the scope of related diversification: the case of small firm accountancy practices, Strategic Management Journal, 2008. 29(8): p. 841-857.

[28] Colurcio, M., Asymmetric business relationships and interaction capabilities: an exploratory study. Sinergie, 2009. 4: p. 109-28.

[29] Sammarra, A., and Biggiero, L., Heterogeneity and specificity of Inter-Firm knowledge flows in innovation networks, Journal of Management Studies, 2008. 45(4): p. 800-829.

[30] Whitley, R., Developing innovative competences: the role of institutional frameworks, Industrial and Corporate Change, 2002. 11(3): p. 497-528.

[31] Avermaete, T., Viaene, J., Morgan, E. J., Pitts, E., Crawford, N., and Mahon, D., Determinants of product and process innovation in small food manufacturing firm, Trends in Food Science \& Technology, 2004. 15(10): p. 474483.

[32] Grunert, K., Valli, C., Designer-made meat and dairy products: consumer-led product development, Livestock Production Science, 2001. 72: p. 83-98.

[33] Cante, C., Calluzzo, V.J., Schwartz, D.P., and Schwartz, T.M., Strategic alliances in food and beverage and executive recruiting industries, Supply Chain Management, 2004. 9(3): p. 230-240.

[34] Olsen, J. R., Harmsen, H., and Friis, A., Product development alliances: factors influencing formation and success, British Food Journal, 2008. 110(4-5): p. 430-443.

[35] Faems, D., Van Looy, B., and Debackere, K., Interorganizational collaboration and innovation: toward a portfolio approach, Journal of product innovation management, 2005. 22(3): p. 238-250.

[36] Menrad, K., Innovations in the food industry in Germany, Research Policy, 2004. 33(6): 845-878.

[37] Capitanio, F., Coppola, A., and Pascucci, S., Indications for drivers of innovation in the food sector, British Food Journal, 2009. 111(8): p. 820-838.

[38] Baregheh, A., Rowley, 0. J., Sambrook, S., and Davies, D., Innovation in food sector SMEs, Journal of Small Business and Enterprise Development, 2012. 19(2): p. 300-321.

[39] De Jong, J. P., and Vermeulen, P. A., Determinants of Product Innovation in Small Firms A Comparison Across Industries, International Small Business Journal, 2006. 24(6): p. 587-609.

[40] Wakelin, K., Innovation and export behaviour at the firm level. Research policy, 1998. 26(7): p. 829-841.

[41] Freel, M. S., and Harrison, R. T., Innovation and cooperation in the small firm sector: Evidence from 'Northern Britain', Regional Studies, 2006. 40(4): p. 289-305.

[42] Najib, M., and Kiminami, A., Innovation, cooperation and business performance: Some evidence from Indonesian small food processing cluster, Journal of Agribusiness in Developing and Emerging Economies, 2011. 1(1): p. 75-96. 
[43] Saunders, M., Lewis, P., and Thornhill, A., Research Methods for Business Students (3rd ed.), 2013. Upper Saddle River, NJ : Prentice Hall.

[44] Raynaud, E., Sauvee, L., and Valceschini, E., Alignment between Quality Enforcement Devices and Governance Structures in the Agro-food Vertical Chains, Journal of Management and Governance, 2005. 9 (47): p. 47-77.

[45] Witzel, A., The problem-centered interview. Forum Qualitative Sozialforschung/Forum: Qualitative Social Research, 2000. available at: www.qualitativeresearch.net/index.php/fqs/article/view/1132 (accessed 15 June 2012).

[46] Kjellberg, H., and Helgesson, C. F., On the nature of markets and their practices, Marketing Theory June, 2007. 7(2): p. 137-162.

[47] Laursen, K. and Salter, A., Open for innovation: the role of openness in explaining innovation performance among UK manufacturing firms, Strategic management journal, 2006.27 (2): p.131-150.

[48] Ellström, P. E., Practice-based innovation: a learning perspective, Journal of Workplace Learning, 2010. 22(1/2): p.27-40. 